\title{
The Distribution of Biomphalaria spp. in Different Habitats in Relation to Physical, Biological, Water Contact and Cognitive Factors in a Rural Area in Minas Gerais, Brazil
}

\author{
Helmut Kloos, Cecilia de Souza*, Andrea Gazzinelli**/+, Britaldo Silveira \\ Soares Filho***, Plinio da Costa Temba***, Jeffrey Bethony****, \\ Kristen Page $* * * *$, Claudia Grzywacz ******, Fred Lewis******', \\ Dennis Minchella ${ }^{* * * *}$, Phillip LoVerde ${ }^{* * * * * * *}$, Rodrigo Corrêa Oliveira****
}

\begin{abstract}
Department of Epidemiology and Biostatistics, University of California, San Francisco, USA, and Visiting Professor, Escola de Enfermagem, Universidade Federal de Minas Gerais, Belo Horizonte, MG, Brasil *Departamento Malacologia ****Departamento de Imunologia, Centro de Pesquisas René Rachou-Fiocruz, Belo Horizonte, MG, Brasil **Escola de Enfermagem ***Departamento de Cartografia, Instituto de Geociências, Universidade Federal de Minas Gerais, Caixa Postal 486, 30161-970 Belo Horizonte, MG, Brasil ***** Department of Biological Sciences, Purdue University, West Lavayette, IN, USA ******Biomedical Research Institute, Rockville, MD, USA ********Department of Microbiology, School of Medicine, State University of New York, Buffalo, NY, USA
\end{abstract}

A total of 256 sites in 11 habitats were surveyed for Biomphalaria in Melquiades rural area (State of Minas Gerais) in August and November 1999 and in March 2000. Of the 1,780 Biomphalaria collected, 1,721 (96.7\%) were B. glabrata and 59(3.3\%) B. straminea. Snails were found in all habitats except in wells, with the largest mean numbers in tanks, seepage ponds and canals, and the smallest numbers in springs, rice fields and fishponds.

People's knowledge of the occurrence of Biomphalaria at the collection sites and the presence of Biomphalaria ova were strongly correlated with the occurrence of snails, and distance between houses and collection sites, as well as water velocity were inversely correlated with Biomphalaria occurrence $(p<0.001)$. The strongest predictor of Biomphalaria occurrence was the presence of tilapia fish in fishponds. Fourteen Biomphalaria (0.8\% of all snails) found at 6 sites were infected with Schistosoma mansoni. Suggestions are made for the utilization of local people's knowledge in snail surveys and further studies are recommended on the possible use of tilapia for biological control of Biomphalaria in fishponds, as well as modeling of $\mathrm{S}$. mansoni transmission and reinfection.

Key words: Biomphalaria glabrata - Biomphalaria straminea - geographic distribution - environmental factors local knowledge - Minas Gerais - Brazil

In view of the wide range of natural and manmade snail habitats in Brazil that are used by humans for domestic, recreational and occupational purposes, it is essential that the distribution of schistosomiasis intermediate hosts be known for the design, implementation and evaluation of con-

\footnotetext{
This study was supported by grants from Programa de Apoio a Grupos de Excelência-Pronex/CNPq/Finep, National Institutes of Health-NIH/ICIDR/Grant AI45451-01, Fundação de Amparo a Pesquisa do Estado de Minas Gerais-Fapemig, Conselho de Desenvolvimento Tecnológico e Científico-CNPq.

${ }^{+}$Corresponding author. Fax: +55-31-3286.8801. E-mail: andreag@enf.ufmg.br

Received 14 May 2001

Accepted 25 July 2001
}

trol programs. Pessoa and Martins (1988) reviewed the literature on the distribution and ecology of Biomphalaria species in Brazil in relation to habitat and noted that this genus has a great capacity to adapt to different environmental conditions. Schmelzer et al. (1997) found B. straminea to be widespread in lakes in Fortaleza city. In small irrigation canals in gardens in Salvador city, B. glabrata was the dominant species (Coutinho 1950).

Seven of the 10 species of Biomphalaria endemic in Brazil occur in Minas Gerais. B. glabrata is the most widespread species, occurring in 257 of the State's 853 municipalities, followed by $B$. straminea $(10.4 \%)$ and B. tenagophila $(4.1 \%)$ (Souza et al. 1997, Souza \& Lima 1997a,b). B. glabrata inhabits mostly small tributary streams in the northeastern part of that State (Freitas 1968). In Belo Horizonte municipality, more streams harbored 
aquatic snails than any other habitat but irrigation canals yielded the largest number of B. glabrata, followed by streams, swamps, drainage canals and ponds, in that order. A number of other investigators pointed out the importance of canals as a habitat of Biomphalaria and transmission site (Pessoa \& Martins 1988).

Past malacological surveys in Brazil failed to study two snail habitats in detail: household water tanks and "bicas" (traditional household water conduits). Household water tanks, including both the older cement tanks on the ground and the newer asbestos and plastic tanks on top of houses, are used for all types of domestic uses, and the cement tanks for cattle watering as well. Most of them being supplied with stream or spring water, they confer considerable risk of schistosomiasis exposure.

Bicas channel canal, stream or spring water via bamboo or (more recently) plastic pipes continue to be used in many rural communities in Brazil either as the primary or as a secondary source of household water. All water-related household activities, including washing dishes and clothes, as well as bathing, are carried out at these sites, with domestic and bathing activities often carried out at different bicas.

Fishponds, increasingly constructed in Brazil and other countries in the tropics for the purpose of supplying protein to increasing populations, have been identified as another potential source of schistosomiasis infection, especially if they are not properly maintained (Editorial 1970, Ferguson \& Ruiz-Tieben 1971). A field trial by Azevedo (1960) in a Brazilian lake indicated that Tilapia melanopleura is a predator of B. glabrata, which was confirmed in the laboratory by Andrade and Antunes (1969). In Bahia, the local fish apaiar (Anthronatus ocelatus) was used for snail control (Naftale Katz, pers. commun.). Several other fish species have been found to be effective predators of snail intermediate hosts, and recently $T$. rendalli and the chichlid Sargochromis codringtoni have been used in schistosomiasis control in fish ponds in Zimbabwe (Chimbari et al. 1999).

A potential source of information on snail distribution, local people's knowledge, has seldom been considered in malacological surveys, which are normally designed by urban-based scientists using preconceived ideas of snail distribution. If local people have reliable information about the occurrence of Biomphalaria they may then become instrumental in working with control teams, in identifying snail habitats and thus schistosome transmission sites. Such local involvement is in agreement with the primary health care approach in schistosomiasis control advocated by the World Health Organization (1990).
Spatial studies of intermediate host snail distribution using computer-based GIS technology have been carried out during recent years for locational accuracy and interactive analysis of results in Brazil (Bavia et al. 1995), Egypt (Malone et al. 1994) and China (Spear et al. 1996). At the community level, the use of DGPS (differential global positioning systems) permitted the preparation of vector maps in rural areas lacking topographic maps (Hightower et al. 1998).

The purpose of this study is to examine the distribution of Biomphalaria in all types of natural and man-made habitats found in the rural area of Melquiades in Governador Valadares Prefecture in the State of Minas Gerais. This study forms part of an epidemiological study of Schistosoma mansoni in Melquiades, which included the administration of mass chemotherapy to the population in 1998/ 1999 (Bethony et al. 2000).

\section{STUDY AREA}

Melquiades is a $100 \mathrm{~km}^{2} / 50 \mathrm{~km}$ west of Governador Valadares city. The Melquiades population of 1,200 lives in 14 hamlets in 12 river valleys, depending on subsistence agriculture involving the growing of corn, beans and rice and raising cattle and commercially grown bananas and dairy products. The study area varies in elevation from 250 to over $900 \mathrm{~m}$, providing considerable precipitation in the mountains and numerous fast-flowing perennial streams. The local population constructed canals for domestic uses, to irrigate rice fields and drain pastures in the stream floodplains. Bicas continue to be used by most households and some have shallow wells. A centralized piped water system with a deep well source was installed by a water utility company in four hamlets (Rua da Grota, Rua dos Bastos, Campo de Futebol, and Rua dos Marinho) in 1997 (Fig. 1). No snail control program has been carried out by the Ministry of Health in Melquiades.

\section{METHODS}

During exploratory snail surveys with the assistance of local farmers and fishermen in November 1998 and March 1999, 256 collection sites were identified. In this selection an attempt was made to include all major water contact sites of the 186 study households at nearby streams and canals and the cement tanks, as well as some of the tanks on roof tops and wells. All bicas and fishponds were included. Away from the hamlets representative streams, irrigation canals and drains, rice fields, swamps, and seepage ponds were sampled. All sites were sampled by the same collector (HK) in August (cool, dry season) and November 1999 (start of rainy season) and March 2000 (end of rains). 


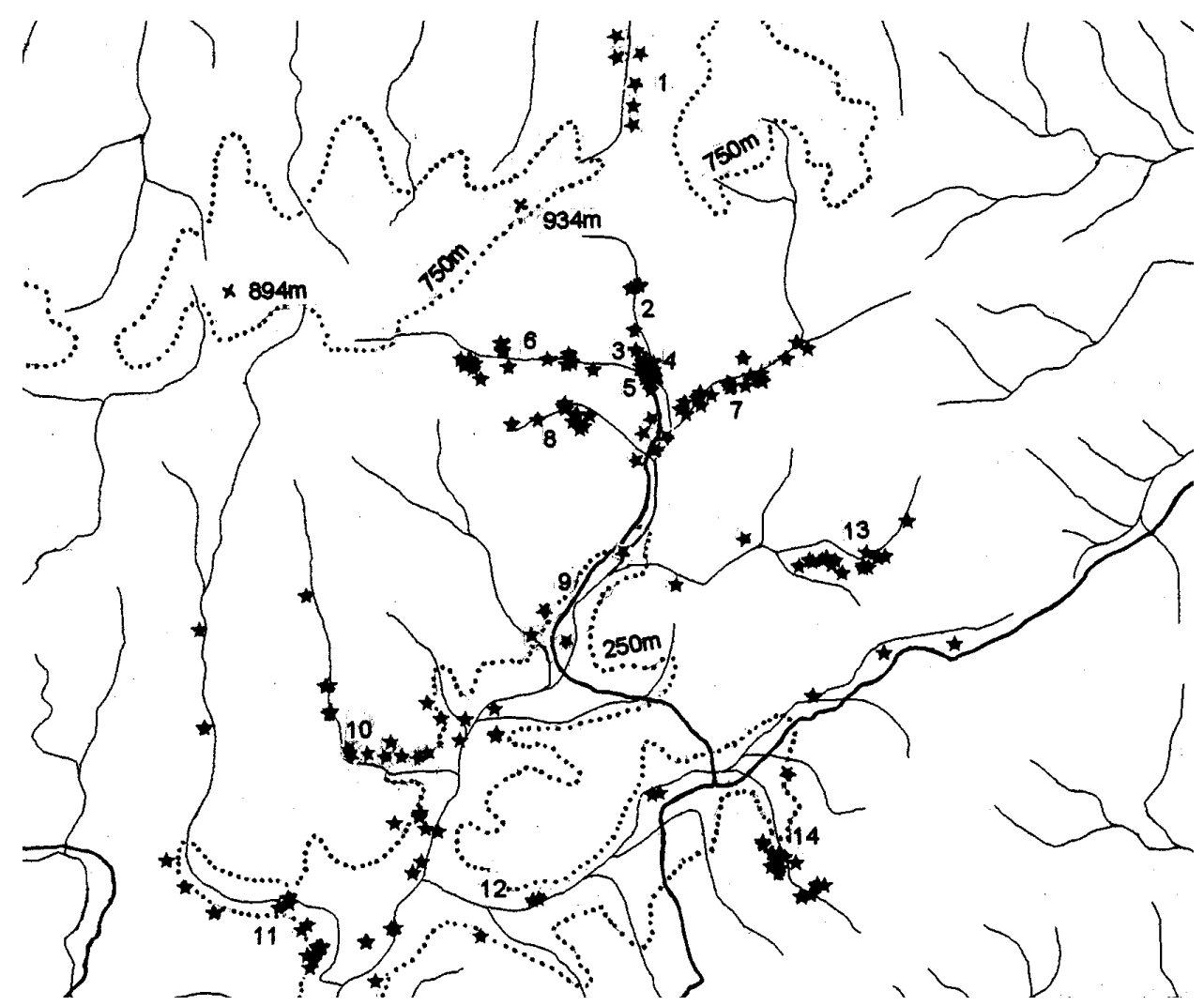

- 1 household

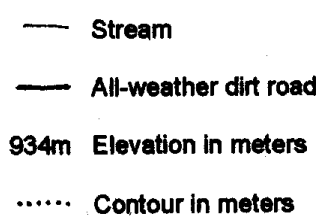

$\stackrel{\mathrm{km}}{0} \quad 5$

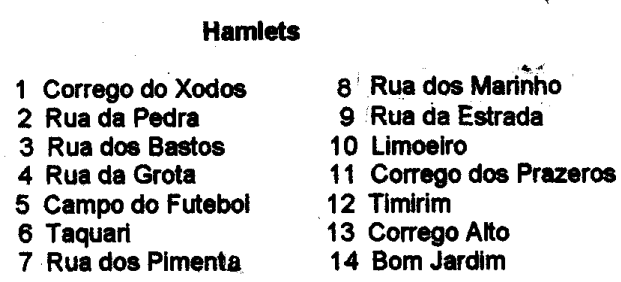

Fig. 1: Melquiades study area: households, hamlets, streams and topography

Each site was surveyed for 5 min using the standard Fiocruz metal scoop (Souza et al. 1997b) and occasionally forceps at rocky sites, on wooden planks and other sites or microhabitats inaccessible with the scoop. Information on number of snails and ova collected, type of habitat, distance to nearest house, whether the site was a water contact site, and physico-biotic characteristics (substrate, vegetation density, visible pollution, water velocity, presence of fish and ducks), and home owners' knowledge about the occurrence of Biomphalaria at the sampled sites on their compounds were recorded on forms at each site. Biomphalaria snails $3 \mathrm{~mm}$ and larger in diameter and ova were collected for identification and snails were measured and shed for cercarea at the Centro de Pesquisas René Rachou in Belo Horizonte and the Biomedical Research Institute in Rockville, USA.

A DGBS (Trimble AgGPS132) system and GIS (MapInfo) software were used to map all snail collection sites, houses and roads after superimposing all georeferenced points on a 1:100,000 scale map to show streams and contours.

\section{RESULTS}

General distribution - Of the 1,780 Biomphalaria collected, 1721 (96.7\%) were B. glabrata 
and $59(3.3 \%)$ B. stramina. Also 252 Physa sp. and 65 Drepanotrema sp. were collected. Biomphalaria snails were recovered from all habitats except wells and from all 14 hamlets, although its spatial distribution varied considerably in some localities and habitats (Figs 1-7). Nearly one-third (30.1\%) of the 1,780 Biomphalaria were collected in August, 858 (48.3\%) in November and 386 (21.7\%) in March. Similarly, 8 of the 24 Biomphalaria ova-positive sites were found in August, 14 in November, 8 in August and only 2 in March. The rains were late in November and had not flushed snails out of their habitats at the time of the survey but were heavy in March. Mean diameter of Biomphalaria in August was $6.8 \mathrm{~mm}$, in November $9.1 \mathrm{~mm}$ and in March $8.0 \mathrm{~mm}$. Twenty-two $B$. glabrata, found in 4 tilapia-free fish ponds, measured $18-26 \mathrm{~mm}$, and the mean size of snails in ponds $(12.4 \mathrm{~mm})$ was larger than in any other habitat. Mean sizes were smallest in streams and canals. Mean diameter of the $56 \mathrm{~B}$. stramina collected during the 3 surveys was $6.6 \mathrm{~mm}$.

Fourteen Biomphalaria snails were infected with S. mansoni, 12 in August (2.2\%) and 2 in March $(0.5 \%)$ (Table I). Infected snails were found in 2 streams, one canal, one cattle tank and two bath bicas. Five of these 6 sites were located in the lowlands below or slightly above the $250 \mathrm{~m}$ contour, although most sites were between 250 and about $600 \mathrm{~m}$ (Figs 1, 2). The infected snails in March were collected from 1 of the bicas used for bathing by a visiting family not included in the study.

Using chi-square and bivariate Pearson correlation tests, statistically significant associations were noted between Biomphalaria snail presence and type of habitat, water velocity (inverse relationship), presence of fish (inverse) and Biomphalaria ova, pollution, distance (inverse) and people's knowledge of snail occurrence. No sig- nificant associations were found with substrate, vegetation density, water contact site, pollution, and presence of ducks (Table II).

Distribution by habitat - At the habitat level, when using bivariate correlation tests, the variable most commonly and most strongly correlated with Biomphalaria presence was "seen Biomphalaria at site" in streams, fishponds and bicas. For tanks this variable was nearly significantly correlated $(\mathrm{P}$ $=0.06$ ). Since both husbands and wives were interviewed and husbands were usually absent from the home during the day only 113 households could be interviewed about this question. The other variables significantly correlated with snail presence are discussed under their respective habitats below.

Streams - Streams had intermediate snail densities. Biomphalaria were most common in the lower portions of major tributary streams and rare in their fast-flowing headwaters. B. glabrata was present in 2 small streams in Taquari and Rua do Marinho just below B. glabrata-positive springs Figs 2, 5). The small streams containing Biomphalaria in their upper reaches either were located in banana farms where banana leaves provided a suitable substrate (Córrego do Xódos, and Rua dos Marinho), or had dense semi-aquatic vegetation (Bom Jardim, and Taquari). In the environmentally variable stream environment the physical variables substrate, vegetation density and water velocity were the strongest predictors of snail presence (Figs 1, 2, Table III). During the rains in March, snail occurrence and density were particularly depressed in streams and none were found in the larger ones.

Springs - Springs at the heads of streams appear to be a major source of Biomphalaria for downstream sites where snails are washed out during the rains. Two of the 3 springs giving rise to

TABLE I

Number of Biomphalaria snails and ova by habitat and sites

\begin{tabular}{lcccc}
\hline Habitat & No. of snails & Mean no. per site & SD & No. of sites with ova (\%) \\
\hline Tanks $(\mathrm{n}=16)$ & 282 & 17.6 & 34.3 & $1(6.3)$ \\
Seepage ponds $(\mathrm{n}=2)$ & 34 & 17.0 & 5.7 & 0 \\
Canals $=27)$ & 419 & 15.5 & 14.7 & $6(22.2)$ \\
Bicas $(\mathrm{n}=62)$ & 389 & 6.3 & 13.3 & $9(14.5)$ \\
Streams $(=53)$ & 324 & 6.0 & 9.8 & $3(5.7)$ \\
Swamps $(\mathrm{n}=5)$ & 28 & 5.6 & 10.9 & 0 \\
Drains $(\mathrm{n}=9)$ & 40 & 4.4 & 4.5 & $1(11.1)$ \\
Fishponds $(\mathrm{n}=62)$ & 232 & 3.7 & 14.6 & $2(3.2)$ \\
Rice fields $(\mathrm{n}=4)$ & 9 & 2.3 & 1.5 & 0 \\
Springs $(\mathrm{n}=11)$ & 23 & 2.1 & 6.3 & $2(18.1)$ \\
Wells $(\mathrm{n}=5)$ & 0 & 0 & - & 0 \\
\hline
\end{tabular}

SD: standard deviation; $\mathrm{n}$ : no of sites 


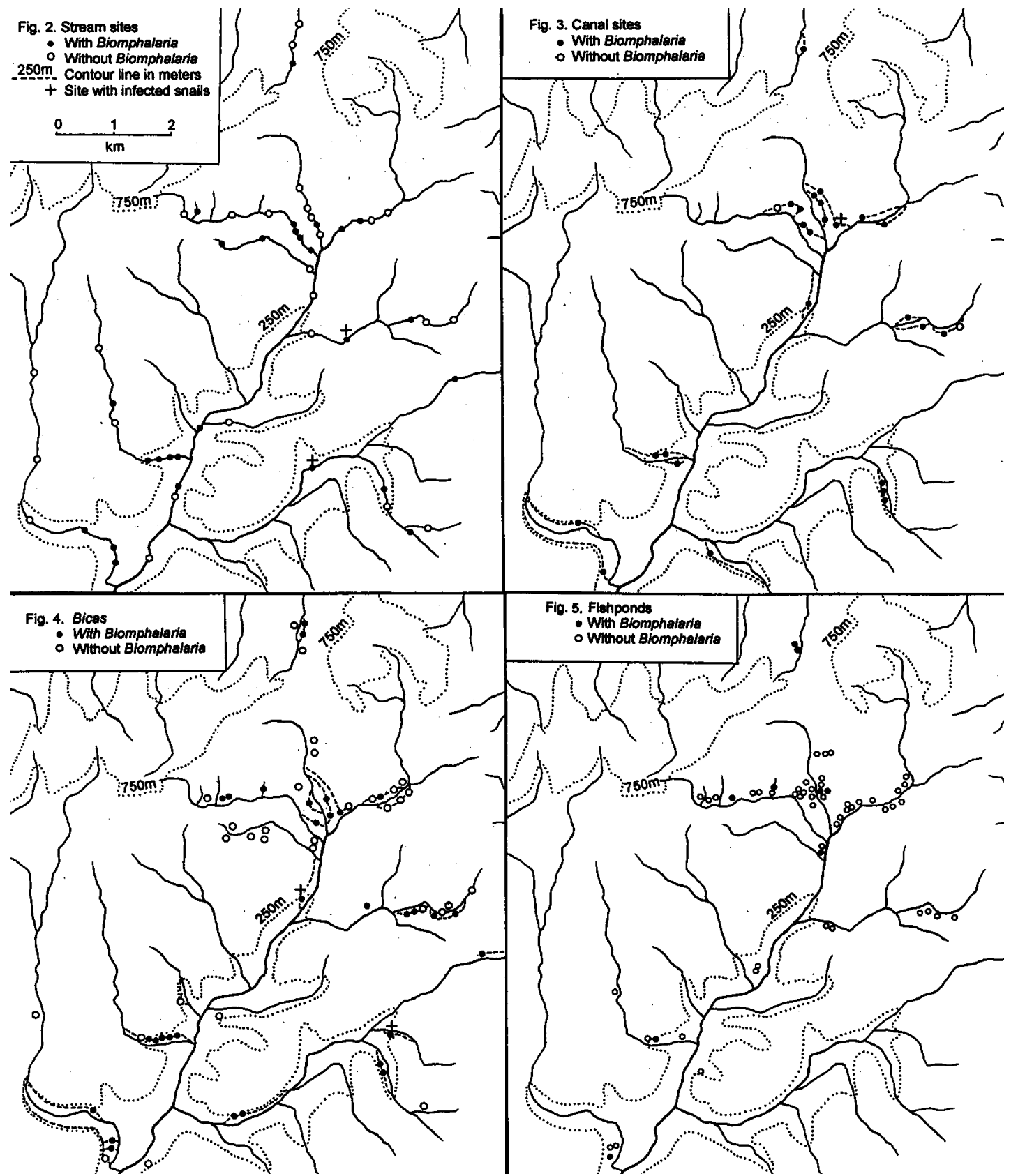

small streams in Taquari and Rua dos Marinho contained both B. glabrata snails and ova. The bica and a fishpond receiving the water from the third spring contained B. glabrata (Figs 1, 4, 5, 6). All dug, open springs around houses were free of snails but 2 bicas and a tank fed by springs via pipes contained B. glabrata.

Canals - All canals surveyed were diverted from streams but their flow was slower, their substrate was mostly clay or organic material instead of the sandy and rocky substrate of streams, and they were thus more heavily vegetated than streams. Food rests from bicas and animal waste were major sources of organic material in canals, contributing to making them favorite snail habitats. Canals contained the largest proportion of Biomphalaria-positive sites $(92.6 \%)$, and among the largest mean number of snails per site. They also had the largest 
TABLE II

Distribution of Biomphalaria among 256 sites in relation to habitat, location, physical, biological, and cognitive variables

\begin{tabular}{|c|c|c|c|c|}
\hline Variables & Sites with snails & Sites without snails & Chi-square & $\mathrm{P}$ (2-sided test) \\
\hline \multicolumn{5}{|l|}{ Habitat } \\
\hline Stream & 27 & 26 & \multirow{6}{*}{49.47} & \multirow{6}{*}{0.000} \\
\hline Canal & 25 & 2 & & \\
\hline Fishpond & 9 & 53 & & \\
\hline Bica & 31 & 31 & & \\
\hline Caixa & 8 & 8 & & \\
\hline Miscellaneous $^{a}$ & 16 & 20 & & \\
\hline \multicolumn{5}{|l|}{ Water velocity } \\
\hline Standing water & 22 & 79 & \multirow{4}{*}{61.26} & \multirow{4}{*}{0.000} \\
\hline Slow $(<10 \mathrm{~cm} / \mathrm{sec})$ & 56 & 22 & & \\
\hline Medium $(10-30 \mathrm{~cm} / \mathrm{sec})$ & 35 & 21 & & \\
\hline Fast $(>30 \mathrm{~cm} / \mathrm{sec})$ & 4 & 19 & & \\
\hline \multicolumn{5}{|l|}{ Presence of fish } \\
\hline No fish present & 52 & 63 & \multirow{3}{*}{41.79} & \multirow{3}{*}{0.000} \\
\hline Species other than tilapia & 59 & 40 & & \\
\hline Tilapia & 1 & 41 & & \\
\hline \multicolumn{5}{|l|}{ Seen Biomphalaria at site ${ }^{b}$} \\
\hline Yes & 25 & 7 & \multirow[b]{2}{*}{30.41} & \multirow[b]{2}{*}{0.000} \\
\hline No & 18 & 63 & & \\
\hline \multicolumn{5}{|l|}{ Biomphalaria ova present } \\
\hline Yes & 22 & 2 & \multirow[b]{2}{*}{22.96} & \multirow[b]{2}{*}{0.000} \\
\hline No & 94 & 138 & & \\
\hline \multicolumn{5}{|l|}{ Distance (m) } \\
\hline $0-19$ & 15 & 32 & \multirow{4}{*}{8.80} & \multirow{4}{*}{0.032} \\
\hline $20-49$ & 46 & 65 & & \\
\hline $50-99$ & 38 & 31 & & \\
\hline$>99$ & 17 & 12 & & \\
\hline \multicolumn{5}{|l|}{ Substrate } \\
\hline Sand/rocks & 5 & 14 & \multirow{5}{*}{5.17} & \multirow{5}{*}{0.271} \\
\hline Sand & 19 & 23 & & \\
\hline Cement & 8 & 9 & & \\
\hline Clay/silt & 80 & 84 & & \\
\hline Organic & 4 & 10 & & \\
\hline \multicolumn{5}{|l|}{ Vegetation density } \\
\hline No vegetation & 45 & 61 & & \\
\hline Sparse & 36 & 48 & & \\
\hline Medium-dense & 28 & 22 & 2.88 & 0.411 \\
\hline Leaves or algae & 7 & 9 & & \\
\hline Water contact site & & & & \\
\hline Yes & 91 & 120 & & \\
\hline No & 25 & 20 & 2.312 & 0.128 \\
\hline Pollution & & & & \\
\hline Not apparent & 76 & 102 & & \\
\hline Iron oxide & 9 & 8 & & \\
\hline Food rests & 16 & 15 & 1.65 & 0.647 \\
\hline Human/animal feces/sewage & 15 & 15 & & \\
\hline Have ducks & & & & \\
\hline Yes & 5 & 7 & & \\
\hline No & 111 & 133 & 0.068 & 0.795 \\
\hline
\end{tabular}

$a$ : includes 11 springs, 9 drainage canals, 5 wells, 5 swamps, 4 rice fields, and 2 seepage ponds; $b$ : only 113 households could be interviewed. 


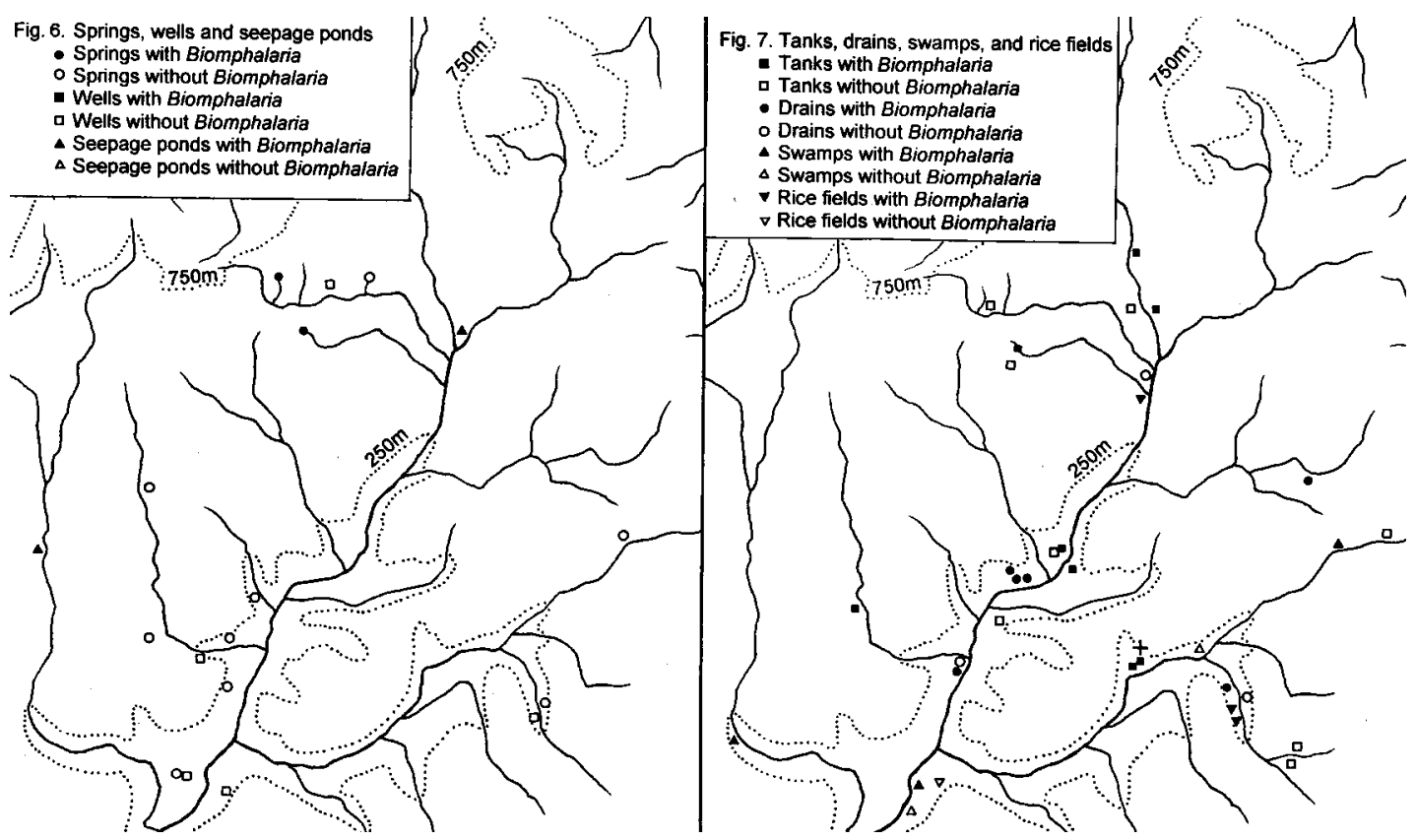

TABLE III

Distribution of Biomphalaria (presence or absence) among 256 sites in relation to location, physical, biological, distance, water contact and cognitive variables, by habitat

\begin{tabular}{llcc}
\hline Habitat & Variables & $\begin{array}{c}\text { Pearson correlation } \\
\text { coefficient }\end{array}$ & Probability \\
\hline Stream $(\mathrm{n}=53)^{a}$ & Substrate & 0.349 & 0.010 \\
Stream $(\mathrm{n}=53)$ & Vegetation density & 0.332 & 0.014 \\
Stream $(\mathrm{n}=53)$ & Water velocity & -0.593 & 0.028 \\
Stream $(\mathrm{n}=18)$ & Seen Biomphalaria snails at site & 0.500 & 0.035 \\
Fishpond $\quad(\mathrm{n}=62)$ & Presence of fish & -0.486 & 0.000 \\
Fishpond $(\mathrm{n}=34)$ & Seen Biomphalaria snails_at site & 0.504 & 0.002 \\
Fishpond $(\mathrm{n}=62)$ & Water contact site & 0.311 & 0.014 \\
Bica $(\mathrm{n}=33)$ & Seen Biomphalaria snails at site & 0.590 & 0.000 \\
Bica $(\mathrm{n}=62)$ & Presence of Biomphalaria ova & 0.321 & 0.011 \\
Bica $(\mathrm{n}=62)$ & Distance $b$ & -0.416 & 0.016 \\
Bica $(\mathrm{n}=62)$ & Pollution & 0.249 & 0.051 \\
Miscellaneous $(\mathrm{n}=36)$ & Water velocity & 0.408 & 0.007 \\
Miscellaneous $(\mathrm{n}=36)$ & Presence of Biomphalaria ova & 0.354 & 0.037 \\
Miscellaneous $(\mathrm{n}=36)$ & Pollution & 0.331 & 0.049 \\
\hline
\end{tabular}

$a$ : number of sites in brackets; $b$ : distance from nearest house to snail collection site

proportion of sites with ova (22.2\%) (Table I, Fig. $3)$. Few snails were found in canals that had been cleaned in March.

Bicas - Twenty-seven of the $33(81.8 \%)$ bicas located on canals and 4 of $29(13.8 \%)$ bicas fed by springs and streams, mostly at higher elevations, had Biomphalaria. Bicas receiving canal water tended to be located at lower elevations and thus received water more likely to be polluted with house- hold and animal waste from households upstream. Many people had seen Biomphalaria swept into their cooking pots and laundry pans by bica water and thus had a good understanding of its seasonal occurrence. Snails and ova were commonly found on rocks, wooden planks, on leaves and in organic matter from food rests, which were the major form of pollution and a predictor of snail occurrence (Table III, Fig. 4). Ten S. mansoni-infected snails were col- 
lected at 2 bicas used for bathing. Presence of ducks was associated with the absence of snails in the immediate vicinity of 3 bicas but not beyond $20 \mathrm{~m}$ upstream and downstream from these collection points, outside the range of ducks.

Fish ponds - The 53 of the 62 fishponds which yielded no Biomphalaria had large tilapia, as ascertained by our observations and information from homeowners. Seventeen of these ponds were said to contain also 8 other fish species, mostly catfish, "cará", "lumbari" and "traíra", all of which were smaller than tilapia. However, homeowners were not always knowledgable about the presence of fish species other than tilápia, the major species they raised for food. Six ponds were devoid of fish, either because they had not been restocked after fish harvest or the fish had died due to excessive pollution by sewage causing anaerobic conditions or from predation by birds and snakes. Three of the 9 ponds populated by Biomphalaria contained "cará", "lumbari" and small tilapia recently introduced into one pond. Fishponds containing tilapia were also free of submerged and emerging vegetation, algae and pond scum.

Presence of fish was a predictor of Biomphalaria presence only in fishponds (Tables II, III). No association was found between snail presence and water source or size or depth of ponds. The negative association between tilapia and Biomphalaria was also noticed in Córrego do Xódos, where a homeowner stocked only one of his two ponds at a time with tilapia. The pond without tilapia in August had hundreds of large snails, as did the other pond devoid of fish in March (Figs $1,5)$. A pond without fish for more than 2 years and fed by canal water in Limoeiro had the largest number of Biomphalaria in any pond (an estimated 20,000 or 200 snails per square meter). Three fishponds accounted for $86.6 \%$ of all Biomphalaria found in this habitat. More than half of all ponds received the effluent from nearby bicas, many of them inhabited by B. glabrata, or sewage from pigpens in an effort to provide organic matter for fish fattening. The owners of two ponds containing Biomphalaria emptied them spontaneously after learning about the presence of schistosomiasis intermediate host snails. Two B. glabrata were found to shed $S$. mansoni cercariae in 1 pond without fish during preliminary surveys in March 1999.

Wells - Neither snails of any species nor any other larger aquatic animals were found in the 5 shallow wells (Fig. 6). They were between 3 and $5 \mathrm{~m}$ deep and 3 of them were covered by boards or plastic and 2 had electric pumps. All wells were used as a supplemental source of water, due to the cost of pumping, the labor involved in pulling up water, and the generally high iron content of well water.
Tanks - The 10 tanks ("caixas") used by humans and the 6 tanks used by cattle received water from springs, streams and canals. One tank on a roof and 4 cement tanks used for household purposes, as well as 3 cattle tanks had $B$. glabrata. Tanks supported the largest mean number of snails of any habitat (Table I), inflated by two cattle tanks containing several hundred of snails each. The positive tank in Rua da Grota distributed water to five houses and the one in Rua dos Marinho to 6 houses via plastic pipes. No association was found between water source and snail presence but maintenance of tanks was a factor. Tanks that were frequently cleaned had relatively fewer snails and less silt and algae. A cattle tank on a large dairy farm in Rua da Estrada treated monthly with lime ("cal") was free of snails, unlike the adjacent untreated ones. A tank in Limoeiro fed by a spring via a halfkilometer long plastic pipe had B. glabrata (Figs 1, 7).

Rice fields - The small canals in three of the four rice fields were used during the rice growing season from November to April and contained $B$. glabrata. Flood-irrigated rice fields in the fourth rice field, in a swampy area of the main stream valley were found to be free of snails. However, they probably contain snails when flooded by the stream, as indicated by the presence of Biomphalaria in the adjacent swamp and information obtained from rice farmers and fishermen (Fig. 7).

Drains - The two of the four drainage canals below rice fields and the four of the five drain sites on cattle pastures were Biomphalaria-positive. Snail density was lowest in March, shortly after canal cleaning (Fig. 7).

Swamps - The three swamps in the stream bottom in the main valley and in Bom Jardim were seasonal swamps inundated by stream water during the rains. They developed eutrophic conditions when the water receded during the dry season, which was corroborated by the dense swamp grass and the near-absence of Biomphalaria and other aquatic animals. Only one live snail, no ova and many empty shells were found. The other two swamps were small, permanent snail habitats located on stream margins (Fig. 7). One of them contained Biomphalaria ova.

Seepage ponds - The 2 permanent seepage ponds adjacent to streams were densely vegetated with submerged and emerging aquatic plants and contained numerous large $B$. glabrata (Fig. 6). Both ponds were seasonally inundated by stream water.

\section{DISCUSSION}

Results of this longitudinal spatial study strongly indicate that connectedness and interde- 
pendency of the different snail habitats, rainfall patterns and certain human activities facilitate the wide distribution of Biomphalaria in Melqiuades. The numerous springs, small streams and the canals with their bicas appear to be the major breeding habitats of snails in Melquiades as indicated by the spatial and temporal distribution of snails. They supply the tanks, swamps, rice fields, drains and seepage ponds with Biomphalaria especially during accelerated snail dispersion in the rainy season. Annual fluctuations in rainfall and the creation and modification of man-made habitats and improvements in water supply and sanitation may thus affect the distribution of Biomphalaria. Use of bicas for washing utensils and laundry, the common practices of nutrient recycling in fishponds and diversion of untreated sewage into the streams may to facilitate snail habitats and increase the risk of schistosomiasis transmission. These and other forms of nutrition recycling involving chicken, pigs and fish are widely practiced by subsistence and commercial farmers in Brazil and need to be studied for their pollution hazard.

Wells are not part of this dynamic snail distribution system due to their location on higher ground, away from the flooding streams, and possibly their water chemistry and lack of vegetation and pollution. Of the more than 30 wells we studied in two other rural communities in northern Minas Gerais only one well was found to contain Biomphalaria, in the rural village of Boa União north of Governador Valadares city (unpublished data). Absence of snails from the developed springs at lower elevations appears to be due to similar factors, because of the similarity of physical characteristics of these two water sources, but this needs further study. Springs are the preferred water source in Melquiades and other rural communities in much of Brazil.

The high level of people's knowledge of Biomphalaria occurrence at their water contact sites and their concern over schistosomiasis transmission have different implications for schistosomiasis control. On the one hand, these results would argue for greater involvement of local populations in the design and implementation of schistosomiasis control programs using the primary health care approach. People in Melquiades showed great interest in the snail surveys and expressed a desire for potable water and sanitation facilities. We were able to locate a number of sites in swamps, streams and drains that contained Biomphalaria with the help of two farmers. The farmer who applied lime to his cattle tanks had done so periodically for several years, after having talked to a veterinarian. Natural S. mansoni infections in cattle have repeatedly been reported from Brazil and lime has been used by farmers as an effective, non-toxic molluscicide for many years in Brazil (Naftale Katz pers. commun.) but no detailed studies or control programs have been initiated (Mott et al. 1995). On the other hand, some studies in rural Brazil have reported a preoccupation with snails as the central force in schistosomiasis transmission that may interfere with control programs by diverting attention away from water supply, sanitation and other control measures (Rozemberg \& Barbosa 1997).

Absence of Biomphalaria from all fish ponds stocked with adult tilapia strongly indicates that this fish is an effective biological control agent in Melquiades. Our results also corroborate the longheld view that management of fish ponds is critical in keeping them free of schistosomiasis intermediate hosts (Berrie 1965, Ferguson and Ruiz-Tieben, 1971). Use of canal or stream water in ponds and failure to stock them with tilapia constitute $S$. mansoni transmission risks in Melquiades. Followup studies are being planned to identify the species of tilapia involved in Melquiades. The impact of guppies (Lebistes reticulatus), which are common in Melquiades, could not be assessed. Several laboratory studies showed that this fish is an efficient predator of $S$. mansoni cercariae (Pellegrino et al. 1966, Knight et al. 1970). Our results of the impact of ducks on snail occurrence are inconclusive due to possible sampling error and the small number of households keeping ducks. The schistosomiasis control program in Brazil includes the introduction of ducks, which have been shown to be effective in reducing Biomphalaria around houses (Naftale Katz, pers. commun. 1999).

This preliminary spatial analysis of Biomphalaria distribution is to be followed with interactive mapping of snails, water supplies, water contact patterns and environmental data in an effort to model $S$. mansoni transmission and reinfection in both snail and humans as part of the ongoing epidemiological study.

\section{ACKNOWLEDGEMENTS}

To the people of Melquiades for their collaboration and Dr Omar S Carvalho for providing literature sources.

\section{REFERENCES}

Andrade RM, Antunes CMF 1969. Combate biológico Tilapia melanopleura Dumeril versus Biomphalaria glabrata (Say) em condições de laboratório. Rev Bras Malariol Doen Trop 21: 49-58.

Azavedo P 1960. Peixes como auxiliares de combate a esquistossomose. Unpublished report. Rio de Janeiro, Departamento Produção Animal, Suepe and Sociedade Brasilieira e Zootecnia.

Bavia M, Hale L, Malone JB 1995. Geographic information systems for control of schistosomiasis in Bahia, Brazil. Am J Trop Med Hyg 53: 220. 
Berrie AD 1965. Fish ponds in relation to the transmission of bilharziasis in East Africa. J Appl Ecol 2: 412-419.

Bethony J, Williams J, Kloos H 2000. Exposure to Schistosoma mansoni infection in a rural area of Brazil. II. Household risk factors. Trop Med Int Health 6: 136145.

Chimbari M, Madsen H, Ndamba J 1999. The potential of using fish to control intermediate host snails for schistosomiasis in Zimbabwe. Proc International Symposium on Schistosomiasis, Rio de Janeiro, p. 31.

Editorial 1970. Fishponds and their health hazards. $\mathrm{Nu}$ trition Rev 28: 155-158.

Ferguson FF, Ruiz-Tieben E 1971. Review of biological control methods for schistosomiasis-bearing snails. Ethiopian Med J 9: 95-104.

Freitas JR 1968. Curso sobre ambiental da esquistossomose. Unpublished report, Universidade Federal de Minas Gerais and Oficina Médica da Saúde, Belo Horizonte.

Gazzinelli A, Bethony J, Alves Fraga L 2000. Exposure to Schistosoma mansoni infection in a rural area of Brazil. I. Water contact. Trop Med Int Health 6: 126135.

Hightower AW, Ombok M, Otieno R 1998. A geographic information system applied to malaria field study in western Kenya. Am J Trop Med Hyg 58: 266-272.

Knight WB, Ritchie LS, Liard F 1970. Cercariophagic activity of guppy fish (Lebistes reticulatus) detected by cercariae labeled with radio selenium (75SE). Am J Trop Med Hyg 19: 620-625.

Malone JB, Huh OK, Fehler DP 1994. Temperature data from satellite imagery and the distribution of schistosomiasis in Egypt. Am J Trop Med Hyg 50: 714722.

Mott KE, Nuttal I, Desjeux P 1995. New geographical approaches to control of some parasitic zoonoses. Bull WHO 73: 247-257.

Pellegrino J, Maria M, Moura MF 1966. Observation on the predation of Lebistes reticulatus (Peters, 1859) on cercariae of Schistosoma mansoni. Am J Trop Med Hyg 15: 337-340.

Pessoa SB, Martins AV 1988. Parasitologia Médica, 11th ed., Gunabara Koogan, São Paulo.

Rozemberg B, Barbosa CS 1997. Social representation of schistosomiasis in endemic areas in southeast (SE) and Northwest Brazil (PE). Proc 6th International Symposium on Schistosomiasis, Belo Horizonte, $\mathrm{p}$. 52.

Schmelzer F, Bezerra M, Neyara SRG 1997. Identification and characterization of the malacological fauna of the lakes at the city of Fortaleza-Ceara, Brazil. Proc 6th International Symposium on Schistosomiasis, Belo Horizonte, p. 130.

Souza CP, Lima LC 1997. Geographic distribution of Biomphalaria in the State of Minas Gerais, Brazil. Proc 6th International Symposium on Schistosomiasis, Belo Horizonte, p. 127.

Souza CP, Lima LC, Konovaloff L 1997. Moluscos limnicos da microregião de Belo Horizonte, MG, com ênfase nos vectores de parasitoses. Rev Soc Bras Med Trop 3: 449-456.

Spear C, Zhou Y, Maszle DR 1996. GIS and schistosomiasis in China. Adv Astronautical Sci 91: 1065-1080.

World Health Organization 1990. Health Education in Schistosomiasis Control, WHO, Geneva. 